\title{
MEMOIRS OF THE
}

SOCIETY FOR AMERICAN ARCHAEOLOGY

Number Fifteen

\section{MODERN YUCATECAN MAYA POTTERY MAKING}

by

RAYMOND H. THOMPSON

Published by

THE SOCIETY FOR AMERICAN ARCHAEOLOGY 


\section{THE SOCIETY FOR AMERICAN ARCHAEOLOGY}

President: George I. Quimby, Chicago Natural History Museum, Chicago 5, Ill.

First Vice-President: Alex D. Krieger, Municipal Museum, Riverside, Calif.

Second Vice-President: Kenneth E. Kidd, Royal Ontario Museum of Archaeology, Toronto 5, Canada.

Secretary: David A. Baerreis, Sterling Hall, Univ. of Wisconsin, Madison 6.

Treasurer: James L. Swauger, Carnegie Museum, Pittsburgh 13, Pa.

Editor: Richard B. Woodbury, Dept. of Anthro., Columbia Univ., New York 27.

Associate Editor for Notes and News: Clement W. Meighan, Dept. of Anthro. and Soc., Univ. of Calif., Los Angeles 24.

Associate Editor for Reviews: Raymond H. Thompson, Dept. of Anthro., Univ. of Arizona, Tucson.

Assistant Editors: Early Man, Alex D. Krieger, Municipal Museum, Riverside, Calif.; Arctic, Elmer Harp, Jr., Dept. of Soc. and Anthro., Dartmouth College, Hanover, N.H.; Pacific Coast, Richard D. Daugherty, Dept. of Anthro, State College of Washington, Pullman; Southwest, Robert H. Lister, Dept. of Anthro., Univ. of Colorado, Boulder; Plains, E. Mott Davis, Dept. of Anthro., Univ. of Texas, Austin 12; Northern Mississippi Valley, Melvin L. Fowler, Illinois State Museum, Springfield; Northeast, Alfred K. Guthe, Rochester Museum of Arts and Sciences, Rochester, N.Y.; Southeast, William H. Sears, Florida State Museum, Gainesville; Middle America, Tatiana Proskouriakoff, Carnegie Institution of Washington, 10 Frisbie Place, Cambridge 38, Mass.; Highland South America, Gerardo Reichel-Dolmatoff, Apartado aéreo 146, Cartagena, Colombia; Lowland South America, Betty J. Meggers, U.S. National Museum, Washington 25, D.C.

Editorial Assistant: Nathalie F. S. Woodbury, Dept. of Anthro., Barnard College, New York 27.

Members of the Executive Committee in addition to elected officers: Robert E. Bell (to 1959), Dept. of Anthro., University of Oklahoma, Norman; Clarence H. Webb (to 1959), 1560 Line Ave., Shreveport, La.; Frederick Johnson (to 1958), R. S. Peabody Foundation, Andover, Mass.; J. Alden Mason (to 1958), University Museum, Univ. of Pennsylvania, Philadelphia 4.

American Antiquity is published by the Societr for AMERICAN ARCHazolooy during the months of January, April, July, and October. Subscription is by membership; annual dues are $\$ 8.00$, of which $\$ 7.00$ is for a subscription to American Antiquity and other publications as issued.

American Antiquity is printed by the University of Utah Press, Salt Lake City 12, Utah.

Entered as second-class matter June 1, 1951, at the post office at Salt Lake City, Utah, under the Act of March 3, 1879.

Orders for back issues and memoirs should be sent to the Society for American Archaeology, Logan Museum, Beloit College, Beloit, Wisconsin. Payment should accompany order. See inside back cover for prices.

Please address requests for membership or other information to the Secretary. 


\section{MEMOIRS OF THE \\ SOCIETY FOR AMERICAN ARCHAEOLOGY}

Number Fifteen

RICHARD B. WOODBURY, Editor 
AMERICAN ANTIQUITY Volume XXIII, Number 4, Part 2, April, 1958

\author{
MEMOIRS OF THE \\ SOCIETY FOR AMERICAN ARCHAEOLOGY
}

Number Fifteen

\title{
MODERN YUCATECAN MAYA POTTERY MAKING
}

by

RAYMOND H. THOMPSON

PUBLISHED BY

THE SOCIETY FOR AMERICAN ARCHAEOLOGY

SALT LAKE CITY, UTAH, U.S.A. 
A. V.K. 
Page

1. The Conceptual Setting ....... 1

The Guiding Principles ......... 1

The Principle of Content ...... 2

The Principle of Indication .... 3

The Principle of Testing ...... 3

The Inferential Process ......... 4

The Indicative Quality ....... 4

The Probative Analogy ....... 5

The Subjective Element ....... 8

2. The Source Materials ........ 9

Historical Notes ............ 11

The Pottery-making Centers ..... 15

Lerma, Campeche ........... 15

Campeche, Campeche ....... 16

Tepakán, Campeche ....... 17

Becal, Campeche ........... 17

Maxcanú, Yucatan .......... 18

Ticul, Yucatán ............ 19

Mama, Yucatán ........... 20

Mérida, Yucatán ........... 21

Izamal, Yucatán ........... 21

Uayma, Yucatán ........... 21

Valladolid, Yucatán ......... 22

Summary $\ldots \ldots \ldots \ldots \ldots \ldots \ldots 23$

3. The Method of Procedure ...... 24

The Basic Assumptions ........ 24

The Archaeological Experiment ... 26

The Ethnographic Presentation .... 28

The Comparative Analysis ...... 30

4. The Archaeological Description. 31

The Material Percepta ........ 31

The Modes ............... 31

The Types $. . . \ldots . . . . . . . .39$

Narrow-mouth Jar . . . . . . . . 39

Wide-mouth Jar ......... 39

Long-neck Jar . . . . . . . . . . . 39

Miniature Jar ............ 39

Single-handled Jar .... . . . . 39

Double-spouted Jar ......... 44

Large Bowl ............ 44

Small Bowl ............. 44

Pedestal Bowl ............. 44

Pedestal Vase ............ 44

Bird-effigy Vessel .......... 48
Flat-rim Dish .......... 48

Shallow Dish ........... 48

Barrel-shaped Vessel ........ 48

Constricted-middle V,essel .... 48

Summary $\ldots \ldots \ldots \ldots \ldots \ldots \ldots \quad 48$

5. An Experiment IN

ARCHAEOLoGical InfERENCE ..... 51

The Inferences ............. 51

The Manufacture of the Vessels. . 51

The Use of the Vessels ....... . 59

Summary of the Inferred

Pottery Techniculture ......... 63

The Manufacture of the Vessels. 63

The Use of the Vessels ........ 64

6. The Ethnographic Description .. 65

The Pottery Techniculture of the Yucatecan Maya ........... 65

The Pottery-making Equipment. . 65

Clay ..................... 65

Grinding Stone .......... 68

Temper $($ sascab $) \ldots \ldots \ldots \ldots 68$

Temper $\left(h i^{\prime}\right) \ldots \ldots \ldots \ldots \ldots 69$

Temper (cuut) .......... 71

Palm-rib Sifter .......... 71

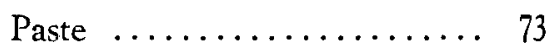

Stool $\ldots \ldots \ldots \ldots \ldots \ldots \ldots .74$

Working Board .......... 76

Pottery Support .......... 76

Water Container .......... 81

Gourd Scraper ........... 81

Measuring Stick ......... 82

Trimming Stick ......... 86

Leather Smoother .......... 86

Incising and Perforating Tool. . 86

Stamp Mold ............ 87

Metal Scraper ............ 87

Corn Cob Smoother ......... 90

Polishing Stone .......... 90

Red Paint .............. 91

Black Paint .............. 94

Pottery Kiln ............ 95

Organic Stain ........... 99

White Paint .............. 100

Water Paint ............. 101

Carrying Frame ......... 101 
The Pottery Manufactures ..... 105

Bowl ................. 105

Powder Container ......... 107

Incense Burner . . . . . . . . . . . 109

Griddle ................ 109

Cooking Pot ............ 113

Water Basin ............. 117

Ceremonial Basin ......... 119

Water-storage Jar ........ 120

Water-carrying Jar ........ 123

Water Canteen ............ 129

Water Cooler ............ 131

Figurine Whistle ......... 136
Summary and Comparative Notes. . 137

The Pottery-making Equipment.. 137

Appearance ............ 137

Name ................ 137

Manufacture ........... 139

Use $\ldots . . . \ldots \ldots \ldots . . .139$

The Pottery Manufactures ..... 144

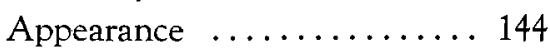

Name ................ 145

Manufacture ........... 145

Use $\ldots \ldots \ldots \ldots \ldots \ldots \ldots 146$

7. Summary and Conclusion $\ldots . . .147$

References Cited .............. 151

\section{LIST OF ILLUSTRATIONS}

The following abbreviations are used in the captions, when referring to museum collections:

AMNH, American Museum of Natural History, New York

$\mathrm{CM}$, Museo Arqueológico, Etnográfico e Histórico de Campeche

CNHM, Chicago Natural History Museum

PM, Peabody Museum of American Archaeology and Ethnology, Harvard University

UM, University Museum, University of Pennsylvania, Philadelphia

Fig. 1. Map: Pottery-making Centers of the Peninsula of Yucatán........ 13

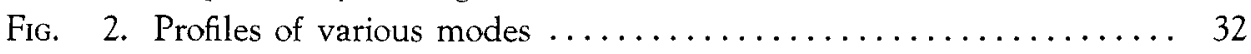

Fig. 3. Profiles of Narrow-mouth Jars $\ldots \ldots \ldots \ldots \ldots \ldots \ldots \ldots \ldots \ldots \ldots \ldots$

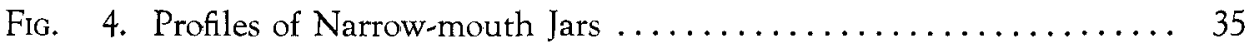

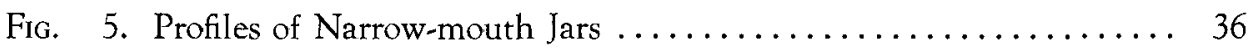

FIG. 6. Profiles of Narrow-mouth Jars $\ldots \ldots \ldots \ldots \ldots \ldots \ldots \ldots \ldots \ldots \ldots$

FIG. 7. Profiles of Wide-mouth Jars $\ldots \ldots \ldots \ldots \ldots \ldots \ldots \ldots \ldots \ldots \ldots . \ldots \ldots$

FIG. 8. Profiles of Wide-mouth Jars and Long-neck Jars . . . . . . . . . . 41

FIG. 9. Profiles of Wide-mouth Jars and Single-handled Jars $\ldots \ldots \ldots \ldots \ldots .42$

FIg. 10. Profiles of Wide-mouth Jars, Double Spouted Jars,

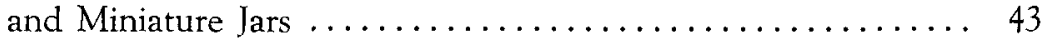

Fig. 11. Profiles of Large Bowls ..................... 45

Fig. 12. Profiles of Large Bowls and Small Bowls ............... 46

Fig. 13. Profiles of Large Bowls ...................... 47

FIg. 14. Profiles of Pedestal Bowls and Pedestal Vases ................... 49

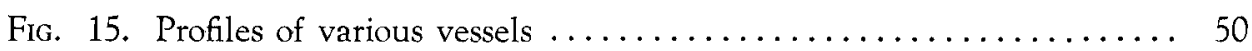

FIG. 16. Clay mine, temper deposit, clay preparation,

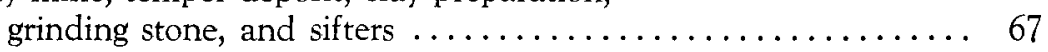

FIG. 17. Stools, working board, and gourd scrapers $\ldots \ldots \ldots \ldots \ldots \ldots \ldots$

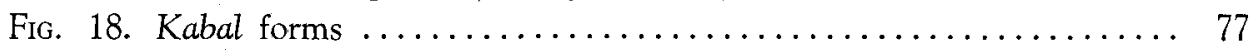

FIG. 19. Miscellaneous pottery-making equipment $\ldots \ldots \ldots \ldots \ldots \ldots \ldots . \ldots 3$

FIG. 20. Pottery making at Lerma $\ldots \ldots \ldots \ldots \ldots \ldots \ldots \ldots \ldots \ldots \ldots \ldots$

FIG. 21. Pottery making at Lerma $\ldots \ldots \ldots \ldots \ldots \ldots \ldots \ldots \ldots \ldots \ldots \ldots$

Fig. 22. Pottery making at Tepakán and Mama $\ldots \ldots \ldots \ldots \ldots \ldots \ldots \ldots$ 